\title{
Physical Examination Sequence Number
}

National Cancer Institute

\section{Source}

National Cancer Institute. Physical Examination Sequence Number. NCI Thesaurus. Code C83356.

An identifier that describes the relative position of physical examination data within a series. 